\title{
Correction to: Monitoring of copper accumulation in water, soil, forage, and cows impacted by heavy automobiles
}

\author{
Tasneem Ahmad $^{1}$. Sonaina Nazar ${ }^{2}$ (D) $\cdot$ Kafeel Ahmad $^{2} \cdot$ Zafar Iqbal Khan $^{2} \cdot$ Humayun Bashir $^{2} \cdot$ Asma Ashfaq $^{2} \cdot$ \\ Mudasra Munir ${ }^{2} \cdot$ Zunaira Munir $^{2} \cdot$ Khadim Hussain $^{3}$ - Jawaher Alkahtani ${ }^{4} \cdot$ Mohamed Soliman Elshikh $^{4}$.

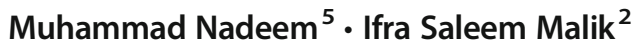

Published online: 3 March 2021

(C) Springer-Verlag GmbH Germany, part of Springer Nature 2021

Correction to: Environmental Science and Pollution Research https://doi.org/10.1007/s11356-021-12770-8

The correct title and project number year in the Funding (RSP2021/193) is presented in this paper.

Publisher's note Springer Nature remains neutral with regard to jurisdictional claims in published maps and institutional affiliations.

The online version of the original article can be found at https://doi.org/ $10.1007 / \mathrm{s} 11356-021-12770-8$

Sonaina Nazar

sonaina.nangiana@gmail.com

1 Pakki Thatti Research and Development Farm, Toba Tek Singh 36050, Pakistan

2 Department of Botany, University of Sargodha, Sargodha 40100, Pakistan

3 Department of Botany, Govt. MAO College, Lahore, Pakistan

4 Department of Botany and Microbiology, College of Science, King Saud University, Riyadh 11451, Saudi Arabia

5 Institute of Food Science and Nutrition, University of Sargodha, Sargodha 40100, Pakistan 